\title{
THE CATION EXCHANGE CAPACITY OF INDUSTRIAL MINERALS AND ROCKS OF MILOS ISLAND
}

\author{
Kantiranis N. ${ }^{1}$, Filippidis A. ${ }^{1}$, Vouta S. ${ }^{1}$, Drakoulis A. ${ }^{1}$, Koutles Th. ${ }^{2}$, and \\ Tzamos E. ${ }^{1}$ \\ ${ }^{1}$ Aristotle University of Thessaloniki, Faculty of Science, Department of Geology, \\ kantira@geo.auth.gr,anestis@geo.auth.gr,s.vouta@gmail.com,alexdr@geo.auth.gr, \\ tzamos@geo.auth.gr \\ ${ }^{2}$ S\&B Industrial Minerals S.A. Voudia, Milos Island,84800 Greece,t.koutles@s.andb.gr
}

\begin{abstract}
Four samples of bentonite, two of perlite, a kaolin and a pumice sample from five mines of Milos Island, have been investigated for their Cation Exchange Capacity (CEC) and the mineralogical composition (wt.\%), by using the Ammonium Acetate Saturation (AMAS) method and X-Ray Powder Diffraction (XRPD) method, respectively. The bentonite samples contain 68-100 wt.\% clay minerals and show CEC values of 35-121 meq/100g, while the kaolin sample contain $41 \mathrm{wt} \%$ clay minerals and show CEC value of $28 \mathrm{meq} / 100 \mathrm{~g}$. The amorphous materials are the main constituent of the perlite samples (73-77 wt.\%) and pumice sample (88wt.\%). The CEC values of perlites were 3-4 meq/100g, while the pumice sample showed a CEC value of 73 meq/100g. The CEC of the samples showed positive correlations with the total content of microporous minerals (clay minerals +micas) as well as with the microporous minerals + amorphous content, mainly affected by the clay minerals content. Key words: bentonite, kaolin, perlite, pumice, CEC.
\end{abstract}

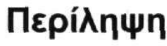

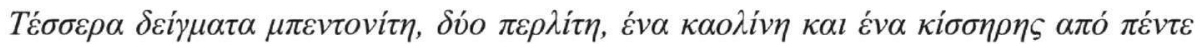

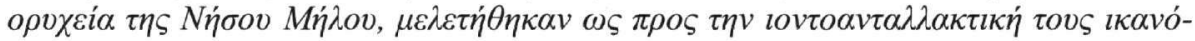

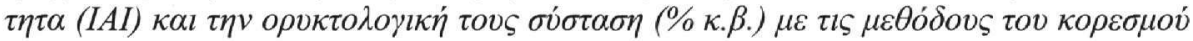

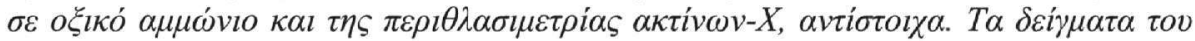

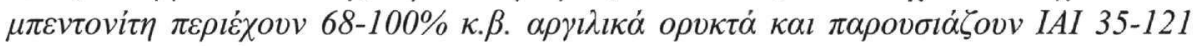

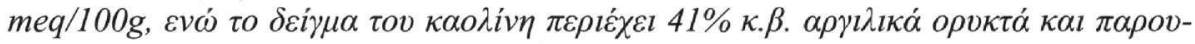

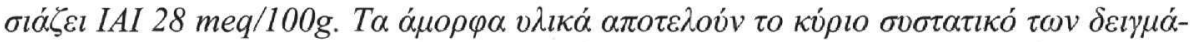

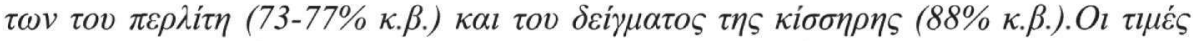

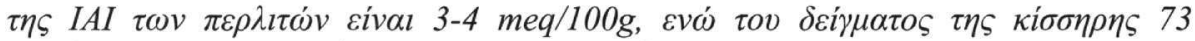

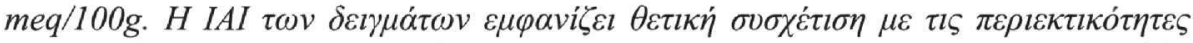

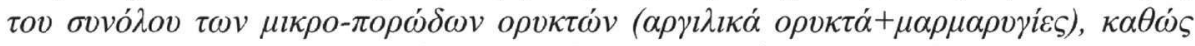

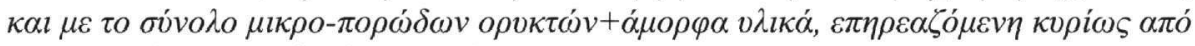

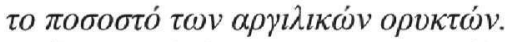

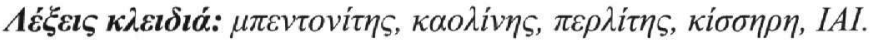




\section{Introduction}

In Milos Island many mineral deposits (bentonite, kaolin, barite, sulphides, sulphates, alunite, perlite, manganese, obsidian, crystalline and non crystalline silica, diatomite, pozzolana and zeolite) are found. The bentonite, kaolin, perlite, barite, pozzolana and amorphous silica are mainly exploited (Decher et al. 1996, Stamatakis et al. 1996, Perraki and Orfanoudaki 1997, Hein et al. 1999, Hein et al. 2000, Drakoulis et al. 2005).

The mineralogical composition and the cation exchange capacity of the industrial minerals are important factors for classifying the type of applications and uses. Concerning perlite and pumice, amorphous-rich industrial minerals, certain uses are affected from the sorption ability of the contained amorphous material, such uses are for perlite: carrier for herbicides, pesticides, insecticides and fertilizers, for pelletizing seed, soil conditioner and rooting medium, and for pumice: soil substitute and additive, catalyst carrier, floor sweep products, acid-washing, grease collector in gas-fired grills, herbicide, fungicide and pesticide carrier (Harben 2002).

In the present paper the cation exchange capacity is correlated with the mineralogical composition of the industrial minerals of Milos Island. In particular, bentonite, kaolin, pumice and perlite have been collected from different mines of the island.

\section{Materials and Methods}

Representative bulk samples having a weight of $\sim 20 \mathrm{~kg}$ each were collected from five mines of the island. More precisely, four samples of bentonite, one of kaolin, one of pumice and two of perlite were collected. The approximate location of the studied samples is shown in Figure 1, while their precise location is given in Table 1. Each sample was ground $(<125 \mu \mathrm{m})$, homogenized and separated into two equal portions. The first portion was used to determine their cation exchange capacity. The second portion was ground further $(<63 \mu \mathrm{m})$ and used for mineralogical analysis.

The semi-quantitative mineralogical composition of the samples was determined by XRay Powder Diffraction (XRPD) method. XRPD analysis was performed using a Philips PW1710 diffractometer with Nifiltered $\mathrm{CuK}_{\alpha}$ radiation on

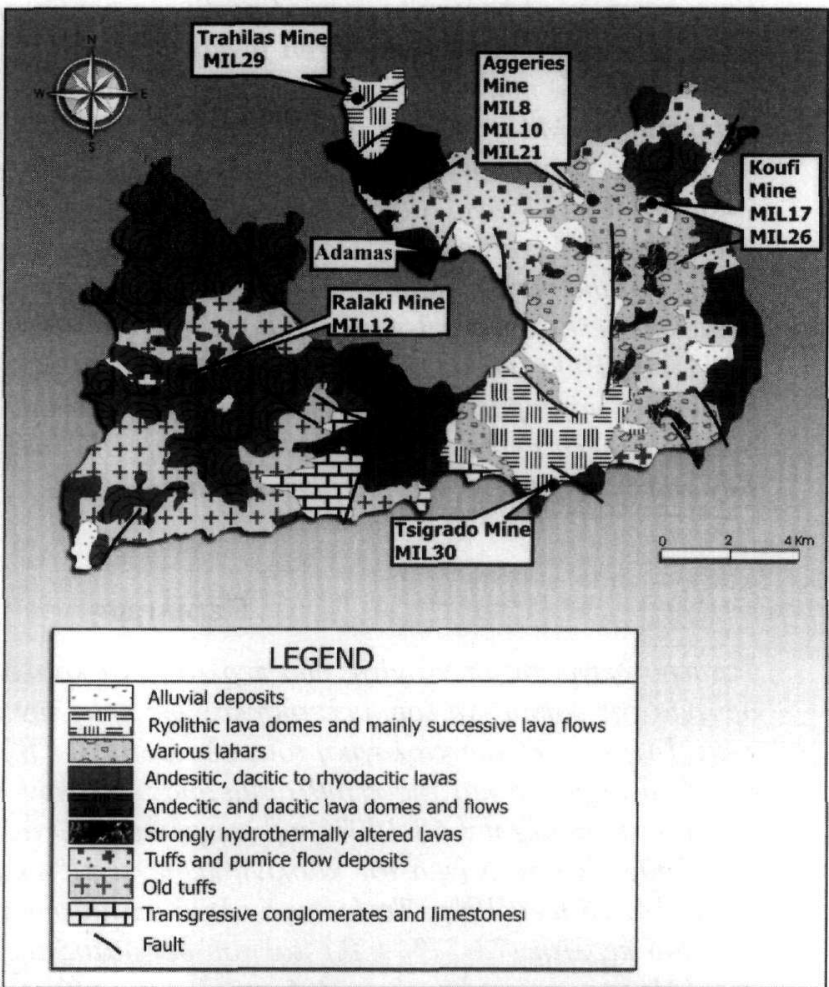

Figure 1 - Simplified geological map of Milos Island (modified after Fytikas 1977) and sample location randomly oriented samples. The samples were scanned from 3 to $63^{\circ} 2 \theta$ at a scanning speed of 1.2 $\% / \mathrm{min}$. Semi-quantitative estimates of the abundance of the mineral phases were derived from the XRPD data, using the intensity of specific reflections, the density and the mass absorption coefficient for $\mathrm{CuK}_{\alpha}$ radiation, for the minerals present. 
The semi-quantitative estimation of the percentage of total amorphous material was achieved by comparing the area of each broad background hump, which represented the amorphous material in each sample, with the analogous area of standard mixtures of minerals with different contents of natural amorphous material, scanned under the same conditions (Kantiranis et al. 2004b, Drakoulis et al. 2005).

The ammonium ion is most commonly used for CEC testing of materials and the results therefore are referred as ammonium exchange capacity. The ammonium cation exchange capacity of the studied samples was determined according to the AMmonium Acetate Saturation (AMAS) method (Kantiranis et al. 2004a, Drakoulis et al. 2005).

\section{Results and discussion}

The semi-quantitative mineralogical compositions and the cation exchange capacity of the studied samples are presented in Table 1. Micas and clays constitute the microporous minerals of the samples, while the non-microporous minerals are quartz, feldspars, calcite, barite and gypsum.

Table 1. Mineralogical composition and cation exchange capasity (CEC) of the studied sumples.

\begin{tabular}{|c|c|c|c|c|c|c|c|c|c|c|c|c|c|c|}
\hline $\begin{array}{l}\text { Location } \\
\text { from Adamas } \\
\text { Village }\end{array}$ & Rock Type & Samples & Mi & $\mathrm{Cl}$ & ТММ & $\mathbf{A}$ & TMM+A & $\mathbf{Q z}$ & Fs & Ce & $\mathbf{B a}$ & Gy & TNM & $\underset{\mathrm{meq} / 100 \mathrm{~g}}{\mathrm{CEC}}$ \\
\hline \multirow{3}{*}{$\begin{array}{l}4.3 \mathrm{~km} \mathrm{E} 22 \mathrm{~N} \\
\text { Aggeries mine }\end{array}$} & Bentonite & MIL8 & - & 100 & 100 & - & 100 & - & - & - & - & - & - & 106 \\
\hline & Bentonite & MIL10 & - & 98 & 98 & 2 & 100 & - & - & - & - & - & - & 121 \\
\hline & Bentonite & MIL21 & - & 68 & 68 & - & 68 & 3 & 2 & - & 16 & 11 & 32 & 35 \\
\hline \multirow{2}{*}{$\begin{array}{l}5.9 \mathrm{~km} \mathrm{E} 15 \mathrm{~N} \\
\text { Koufi mine }\end{array}$} & Bentonite & MIL17 & - & 96 & 96 & - & 96 & 2 & - & 2 & - & - & 4 & 93 \\
\hline & Pumice & MIL26 & - & - & - & 88 & 88 & 12 & - & - & - & - & 12 & 73 \\
\hline $\begin{array}{l}8.4 \mathrm{~km} \mathrm{~W} 24 \mathrm{~S} \\
\text { Ralaki mine }\end{array}$ & Kaolin & MIL12 & - & 41 & 41 & 8 & 49 & 22 & 2 & 27 & - & - & 51 & 28 \\
\hline $\begin{array}{l}5.3 \mathrm{~km} \mathrm{~N} 31 \mathrm{~W} \\
\text { Trahilas mine }\end{array}$ & Perlite & MIL29 & 5 & - & 5 & 73 & 78 & 17 & 5 & - & - & - & 22 & 3 \\
\hline $\begin{array}{l}7.2 \mathrm{~km} \mathrm{S23E} \\
\text { Tsigrado mine }\end{array}$ & Perlite & MIL30 & - & - & - & 77 & 77 & 18 & 5 & - & - & - & 23 & 4 \\
\hline
\end{tabular}

Clay-rich samples (bentonite and kaolin) and amorphous-rich samples (pumice and perlite) were identified in the investigated materials. The bentonite samples contained 68-100 wt.\% montmorillonite, while the kaolin sample contained 41 wt. $\%$ kaolinite. The pumice and perlite samples contained $73-88$ wt.\% amorphous material.

Several researchers in their individual sampling of bentonite, pumice and perlite from near-about the same mines or locations, rendered more or less similar results concerning the composition of clay minerals for bentonites (Decher et al. 1996, Kantiranis et al. 2005) and amorphous material for pumice and perlite (Drakoulis et al. 2005). The similarities apply for the cation exchange capacity concerning the bentonites (Kantiranis et al. 2005). The higher CEC values for perlites and pumice are mainly explained by the differences observed in the chemistry of the amorphous material contained in their samples (Drakoulis et al. 2005).

The CEC of the samples mainly depends on the type and content of the clay mineral. A good positive correlation is observed between CEC and the clay mineral content of the samples (Fig. 2). The same good positive correlation exists between the CEC and the total microporous minerals (clay minerals+micas) of the samples (Fig. 3). A general positive correlation exists between CEC and the total microporous minerals+amorphous material (Fig. 4), since amorphous materials includes anionic charges that are responsible for the sorption ability of the amorphous materials, 


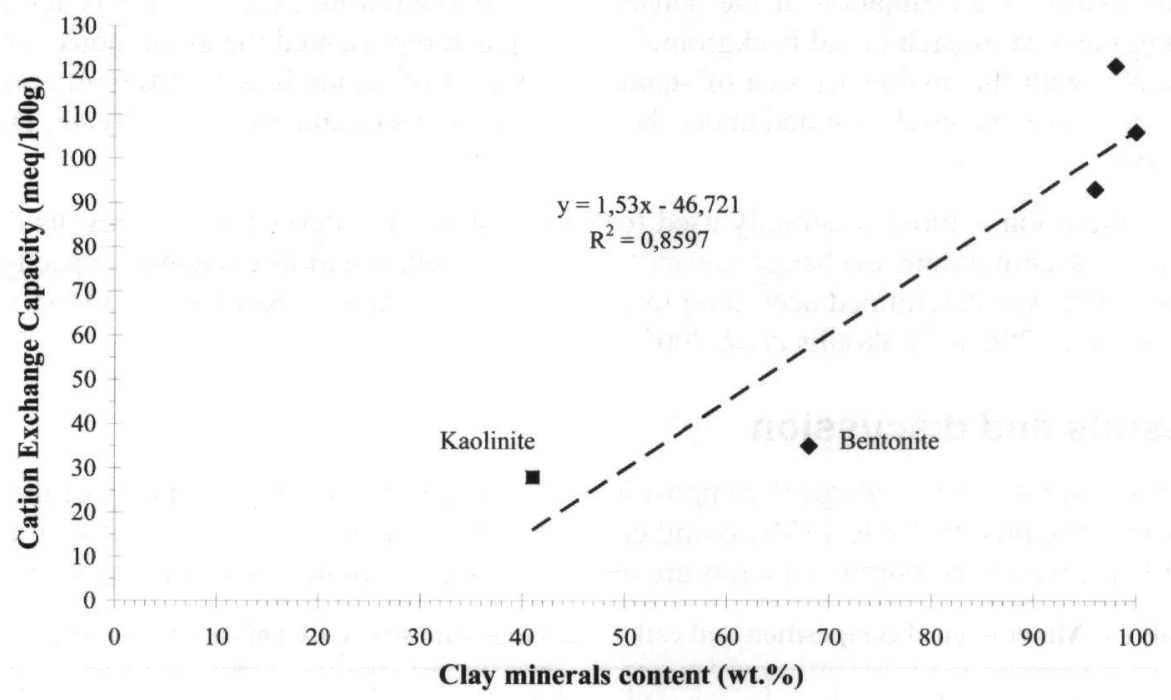

Figure 2 - Correlation between CEC and clay minerals content

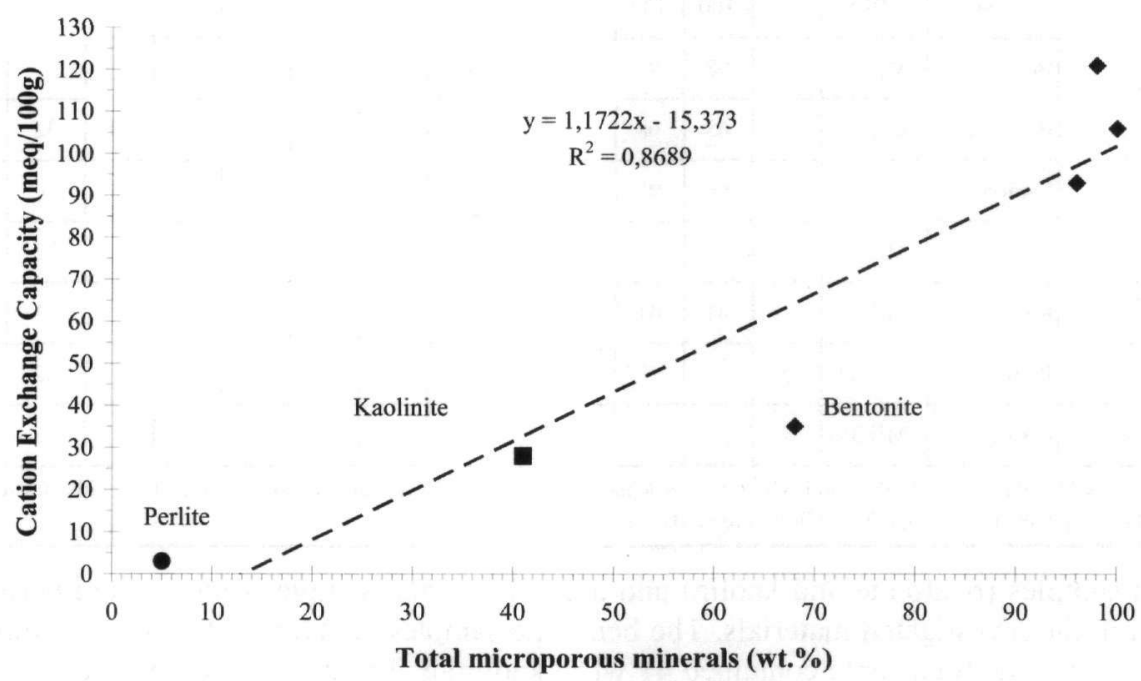

Figure 3 - Correlation between CEC and total microporous minerals

depending on their chemistry (Drakoulis et al. 2005). The pumice sample (CEC $73 \mathrm{meq} / 100 \mathrm{~g}$ ) seems to include much more anionic charges than the perlite samples with negligible CEC values ( $3 \& 4 \mathrm{meq} / 100 \mathrm{~g}$ ), resulting to a modest correlation presented in Fig. 4.

\section{Conclusions}

The bentonite samples contain up to $100 \mathrm{wt} . \%$ clay minerals and the Cation Exchange Capacity (CEC) reaches values up to $121 \mathrm{meq} / 100 \mathrm{~g}$. The kaolin sample contains $41 \mathrm{wt} \%$ clay minerals and exhibit a CEC value of $28 \mathrm{meq} / 100 \mathrm{~g}$. The perlite and pumice samples are mainly rich in amorphous material (up to $88 \mathrm{wt} . \%$ ) and show very low CEC values ( 3 and $4 \mathrm{meq} / 100 \mathrm{~g}$ ), while the pumice sample show a much higher CEC value of $73 \mathrm{meq} / 100 \mathrm{~g}$. The cation exchange capacity of the studied industrial minerals show a positive correlation with clay minerals content, as well as with the microporous minerals (clay minerals+micas)+amorphous materials. The cation exchange 


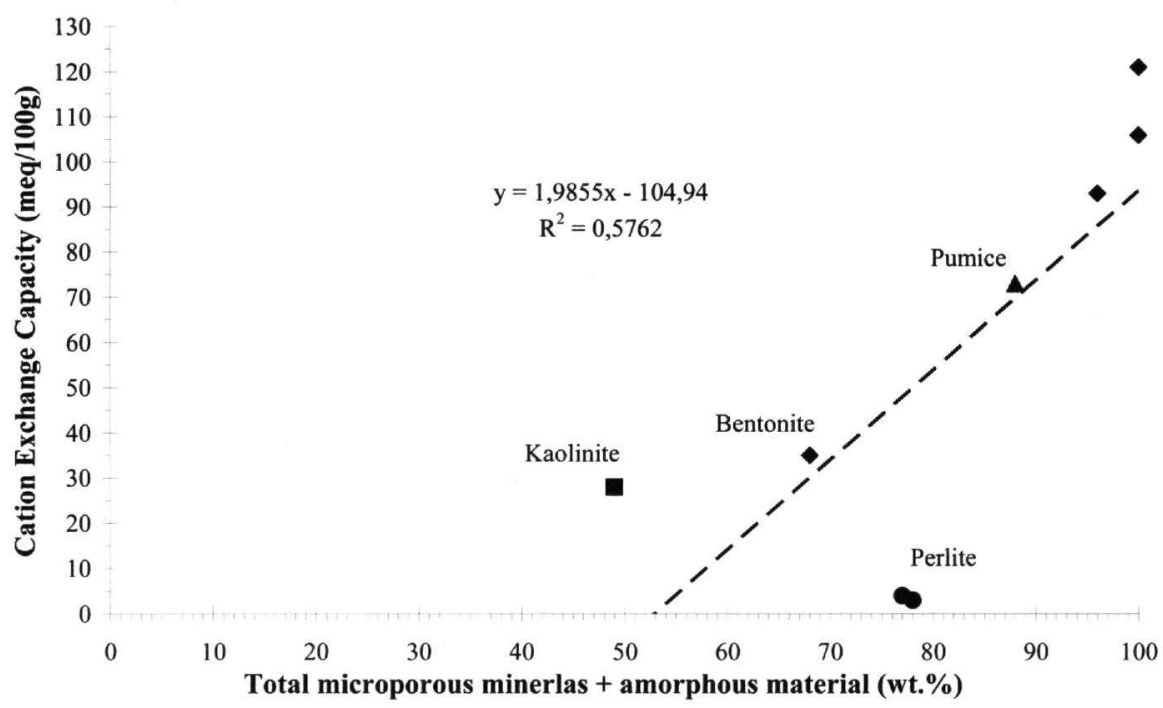

Figure 4 - Correlation between CEC and total microporous minerals + amorphous material

capacity is mainly affected by the clay minerals contained in the rock samples. The amorphous material probably affected to a less extent the CEC values, depending on their chemistry and despite of their lack in crystallinity, since the chemical structure of the amorphous material includes anionic charges and thus may result to their sorption ability.

\section{Acknowledgments}

Thanks are expressed to S\&B Industrial Minerals SA staff of Voudia Headquarters, especially Mr. A. Kefalas for his valuable assistance in the fieldwork and getting permissions of sampling.

\section{References}

Decher, A., Bechtel, A., Echle, W., Friedrich, G., and Hoernes, S., 1996. Stable isotope geochemistry of bentonites from the island of Milos (Greece), Chemical Geology, 129, 101-113.

Drakoulis, A., Kantiranis, N., Filippidis, A., and Sergiou, A., 2005. The uptake ability of amorphous-rich industrial materials from Milos Island, Proc. $2^{\text {nd }}$ Congr. Econ. Geol.-Geochem. Com. of Geol. Soc. Greece, Thessaloniki, 7-9 October, 55-63 (in Greek with English abstract).

Fytikas, M., 1977. Geological map of Greece. Sheet: Milos Island, scale: 1:25.000. IGME, Athens.

Harben, W.P., 2002. The industrial minerals handybook, A guide to markets, specifications \& prices, $4^{\text {th }}$ Edn. Blackwood UK, Pensord, 409 pp.

Hein, J.R., Dowling, J., and Stamatakis, M.G., 1999. Hydrothermal Mn-oxide deposit rich in Ba, $\mathrm{Zn}, \mathrm{As}, \mathrm{Pb}$ and $\mathrm{Sb}$, Milos Island, Greece. In Stanley, et al., (eds) Mineral Deposits: Processes to Processing, 519-522, Balkema, Rotterdam, 1500pp.

Hein, J.R., Stamatakis, M.G., and Dowling, J.S., 2000. Trace Metal-rich Quaternary Hydrothermal Manganese Oxide and Barite Deposit, Milos Island, Greece, Trans. Instn Min. Metall. (Section B), 109, 67-76.

Kantiranis, N., Stamatakis, M., Filippidis, A., and Squires, C., 2004a. The uptake ability of clinoptilolitic tuff of Samos Island, Bull. Geol. Soc. Greece, 36, 89-96. 
Kantiranis, N., Stergiou, A., Filippidis, A., and Drakoulis, A., 2004b. Calculation of the precentage of amorphous material using PXRD paterns, Bull. Geol. Soc. Greece, 36, 446-453. (in Greek with English abstract)

Kantiranis, N., Filippidis, A., Drakoulis, A., and Tsirambides, A., 2005. Study of uptake ability of Milos bentonite and Grevena attapulgite, Proc. $2^{\text {nd }}$ Congr. Econ. Geol.-Geochem. Com. of Geol. Soc. Greece, Thessaloniki, 7-9 October, 105-112. (in Greek with English abstract)

Perraki, Th., and Orfanoudaki, A., 1997. Etude de la composition mineralogique et de proprietes physiques des bentonites de l' ile de Milos (Grece), Mineral Wealth, 104, 35-42. (in Greek with French summary)

Stamatakis, G.M., Lutat, U., Regueiro, M., and Calvo, P.J., 1996. Milos: The mineral island, Industrial Minerals, 341, 57-61. 